\title{
A new Malthodes and some other interesting soldier beetles (Coleoptera: Cantharidae) from Late Eocene Rovno amber
}

\section{Новый Malthodes и некоторые другие интересные жкуки- мягкотелки (Coleoptera: Cantharidae) из позднеэоценового ровенского янтаря}

\author{
Sergey V. Kazantsev ${ }^{1}$ \& Evgeny E. Perkovsky ${ }^{2}$ \\ С.В. Казанцев ${ }^{1}$, Е.Э. Перковский ${ }^{2}$
}

\footnotetext{
${ }^{1}$ Insect Centre, Donetskaya 13-326, Moscow 109651, Russia. E-mail: kazantss@mail.ru

${ }^{2}$ Schmalhausen Institute of Zoology, Bogdan Khmelnitski str. 15, Kiev 01601, Ukraine. E-mail: perkovsk@gmail.com

${ }^{1}$ Инсект-центр, ул. Донецкая 13-326, Москва 109651, Россия.

2 Институт зоологии им. И.И. Шмальгаузена, ул. Б. Хмельницкого 15, Киев 01601, Украина.
}

KEY WORDS: Coleoptera, Cantharidae, new species, amber, palaeontology, Eocene, Ukraine.

КЛЮЧЕВЫЕ СЛОВА: Coleoptera, Cantharidae, новый вид, янтарь, палеонтология, эоцен, Украина.

ABSTRACT. A new fossil species, Malthodes rovnoensis sp.n., is described from the Rovno amber. Mimoplatycis notha Kazantsev, 2013 and Cacomorphocerus sp. are for the first time signalled from the Rovno amber. A list of the fossil Malthodes species, now including seven taxa, is provided.

РЕЗЮМЕ. Из ровенского янтаря описывается новый ископаемый вид, Malthodes rovnoensis sp.n. Mimoplatycis notha Kazantsev, 2013 и Cacomorphocerus sp. впервые приводятся из ровенского янтаря. Приводится список ископаемых Malthodes, который сейчас включает семь видов.

\section{Introduction}

So far six fossil species of the cantharid genus Malthodes Kiesenwetter, 1852 have been known [Kazantsev, 2013], five described from the Baltic or Rovno ambers [Kuśka \& Kupryjanowicz, 2005; Kuśka \& Kania, 2010; Kazantsev, 2010] and one from the Brunstatt brown coals of Alsace [Förster, 1891]. Another taxon previously referred to this genus, Malthodes sucinopenninus Kuśka et Kania, 2010, was transferred to Macrocerus Motschulsky, 1845 [Kazantsev, 2013].

A possibility to study further Rovno amber specimens from the collection of the Schmalhausen Institute of Zoology in Kiev yielded yet another fossil Malthodes. Description of this new taxon is presented below, along with first records of the genera Mimoplatycis Kazantsev, 2013 and Cacomorphocerus Schaufuss, 1892 in Rovno amber.

\section{Material and Methods}

Studied specimens were found in Pugach quarry (Klesov) [Perkovsky et al., 2010], some doubts we have only about the provenance of specimen UA-2286. The amber specimens with the insect inclusions were polished at their sides allowing best dorsal, ventral, anterior and lateral views of the included beetles. For examination and preparing the illustration MSP-1 stereo dissecting microscope with $8 \mathrm{x}-80 \mathrm{x}$ magnification range was used. Photographs were taken with Canon EOS 6D camera and Canon MP-E $65 \mathrm{~mm}$ lens. All specimens are deposited in Schmalhausen Institute of Zoology, Kiev (SIZK).

\section{Taxonomy}

Malthodes rovnoensis Kazantsev et Perkovsky, sp.n. Figs 1-6

MATERIAL: Holotype, $\sigma^{7}$, specimen SIZK No. K-25818, Klesov, Rovno amber, Late Eocene. DESCRIPTION. Male. Brownish; head black.

DESCRIPTION. Head noticeably narrowed behind eyes. Eyes relatively small, interocular dorsal distance ca. 1.4 times greater than eye diameter. Terminal palpomeres roundish, distally pointed. Antennae filiform, attaining to elytral apices, with antennomere $3 \mathrm{ca} .1 .3$ times longer than pedicel (antennomere 2) and subequal in length to antennomere 4; pubescence erect, relatively long (Figs 1-4).

Pronotum transverse, ca. 1.5 times wider than long, almost straight at sides, margined throughout, with almost straight anterior and posterior margins, noticeable anterior and posterior angles (Figs 1-4). Scutellum elongate, triangular, rounded at apex.

Elytra elongate, ca. 3 times longer than wide at humeri, shortened, covering two thirds of abdomen, shining, almost 


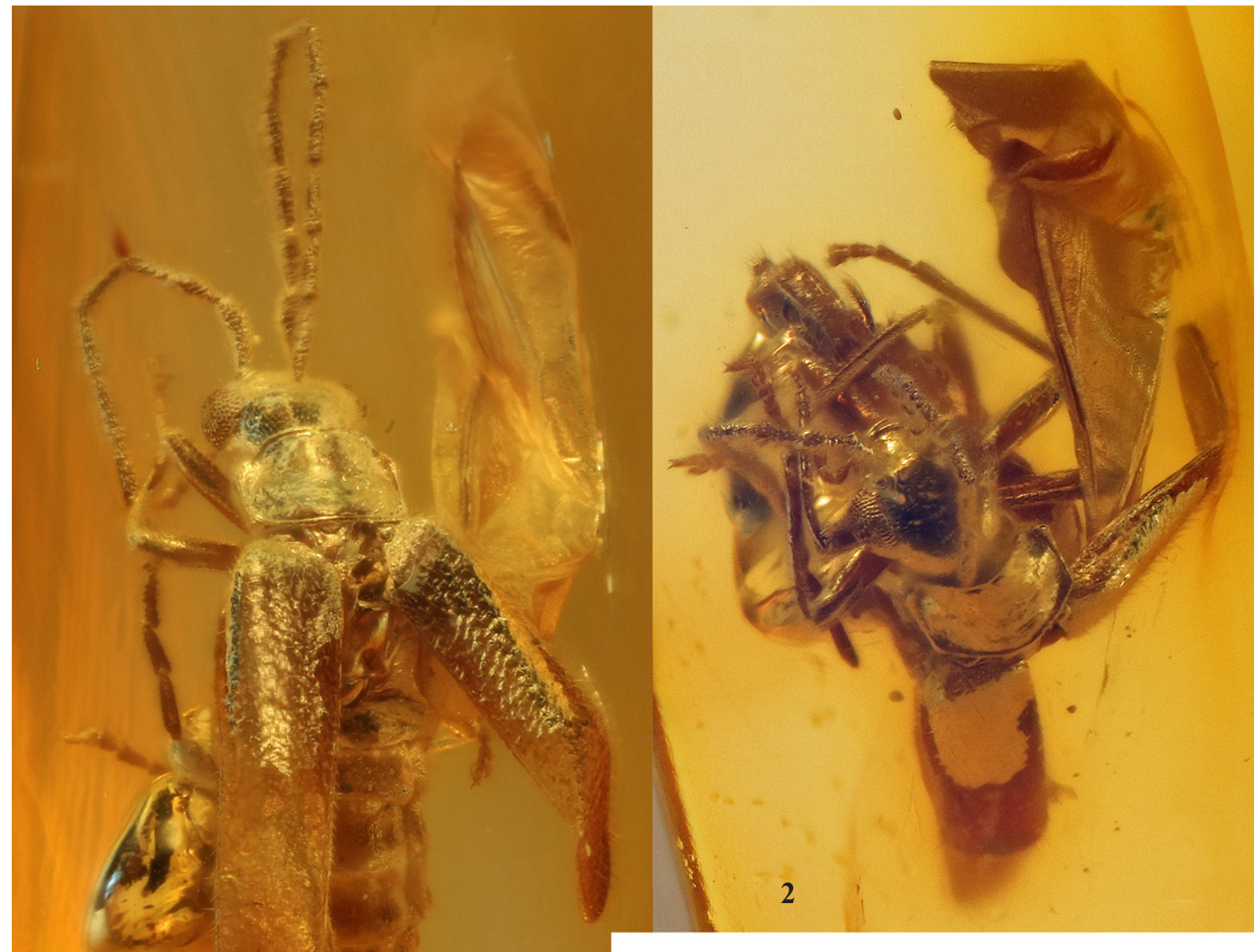

Figs 1-2. General view of Malthodes rovnoensis sp.n., holotype male: 1 - dorsally; 2 - antero-ventrally. Scale bar: $1 \mathrm{~mm}$.

Рис. 1-2. Общий вид Malthodes rovnoensis sp.n., голотип, самец: 1 - сверху; 2 - спереди и снизу. Масштаб: 1 мм.

Aedeagus with a pair of widened distally ventral processes and ventrally directed spine of the median lobe (Fig. 6).

Length (from anterior head margin to end of abdomen): ca. $2.5 \mathrm{~mm}$. Width (humeral): ca. $0.6 \mathrm{~mm}$.

Female. Unknown.

ETYMOLOGY. The new species is named after the Lagerstätte.

DIAGNOSIS. Malthodes rovnoensis sp.n. somewhat resembles M. minimus Linnaeus, 1758, widely distributed in Europe and northern Asia, similar in the shape of the aedeagus, but differing by the margined laterally pronotum and elongate and only shallowly emarginate ultimate ventrite (Figs 1-6). It may be differentiated from M. perkovskyi Kazantsev, 2010, also from the Rovno amber, by the short and small ultimate tergite and shallowly emarginate ultimate ventrite (Figs 5-6).

parallel-sided, separately rounded at apices, with large obscure punctures (Figs 1-4).

Legs slender, tibiae straight, slightly longer than femurs; tarsomeres 1-2 narrow, without plantar pad, tarsomeres 3-4 widened, with plantar pad (Figs 1-4).

Ultimate ventrite elongate, slightly concave at sides shallowly and broadly emarginate at apex, penultimate ventrite broad, without lateral processes; ultimate tergite simple, small, very short, penultimate tergite broad, without lateral processes (Figs 5-6).

A list of the currently known fossil members of the genus Malthodes, which includes seven species, is presented below.

Genus Malthodes Kiesenwetter, 1852

type species Malthinus marginatus Latreille, 1806

ceranoviczae Kuśka et Kupryjanowicz, 2005: 310. Baltic amber. Late Eocene.

kotejai Kuśka et Kupryjanowicz, 2005: 311. Baltic amber. Late Eocene. 

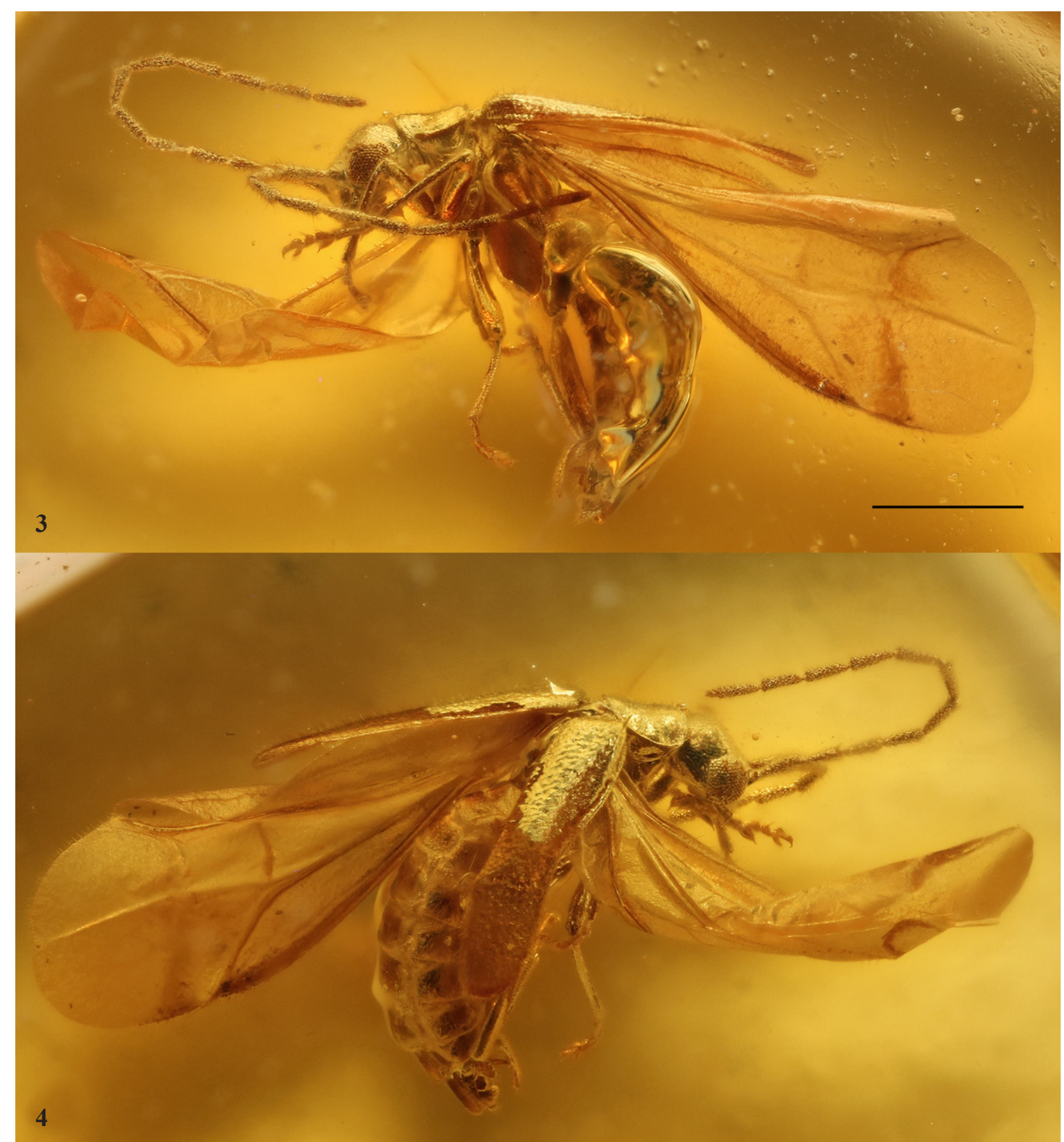

Figs 3-4. General view of Malthodes rovnoensis sp.n., holotype male: 3 - laterally, left side; 4 - laterally, right side. Scale bar: $1 \mathrm{~mm}$.

Рис. 3-4. Общий вид Malthodes rovnoensis sp.n., голотип, самец: 1 - слева; 2 - справа. Масштаб: 1 мм.

obtusus Förster, 1891: 373. Brunstatt brown coals of Alsace. End of Eocene.

perkovskyi Kazantsev, 2010: 105. Rovno amber. Late Eocene.

rovnoensis Kazantsev et Perkovsky, 2014, sp.n. Rovno amber. Late Eocene.

serafini Kuśka et Kupryjanowicz, 2005: 312. Baltic amber. Late Eocene.

sucini Kuśka et Kania, 2010: 55. Baltic amber. Late Eocene.

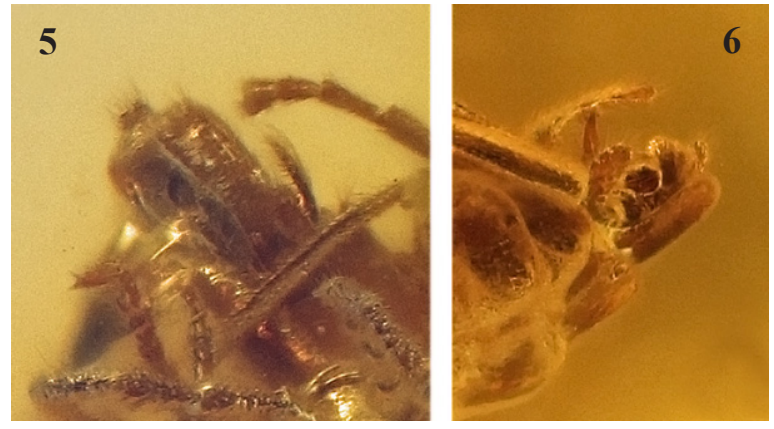

Figs 5-6. Terminal abdominal segments of Malthodes rovnoensis sp.n., holotype male: 5 - ventrally; 6 - laterally.

Рис. 5-6. Вершинные сегменты брюшка Malthodes rovnoensis sp.n., голотип, самец: 5 - снизу; 6 - сбоку. 


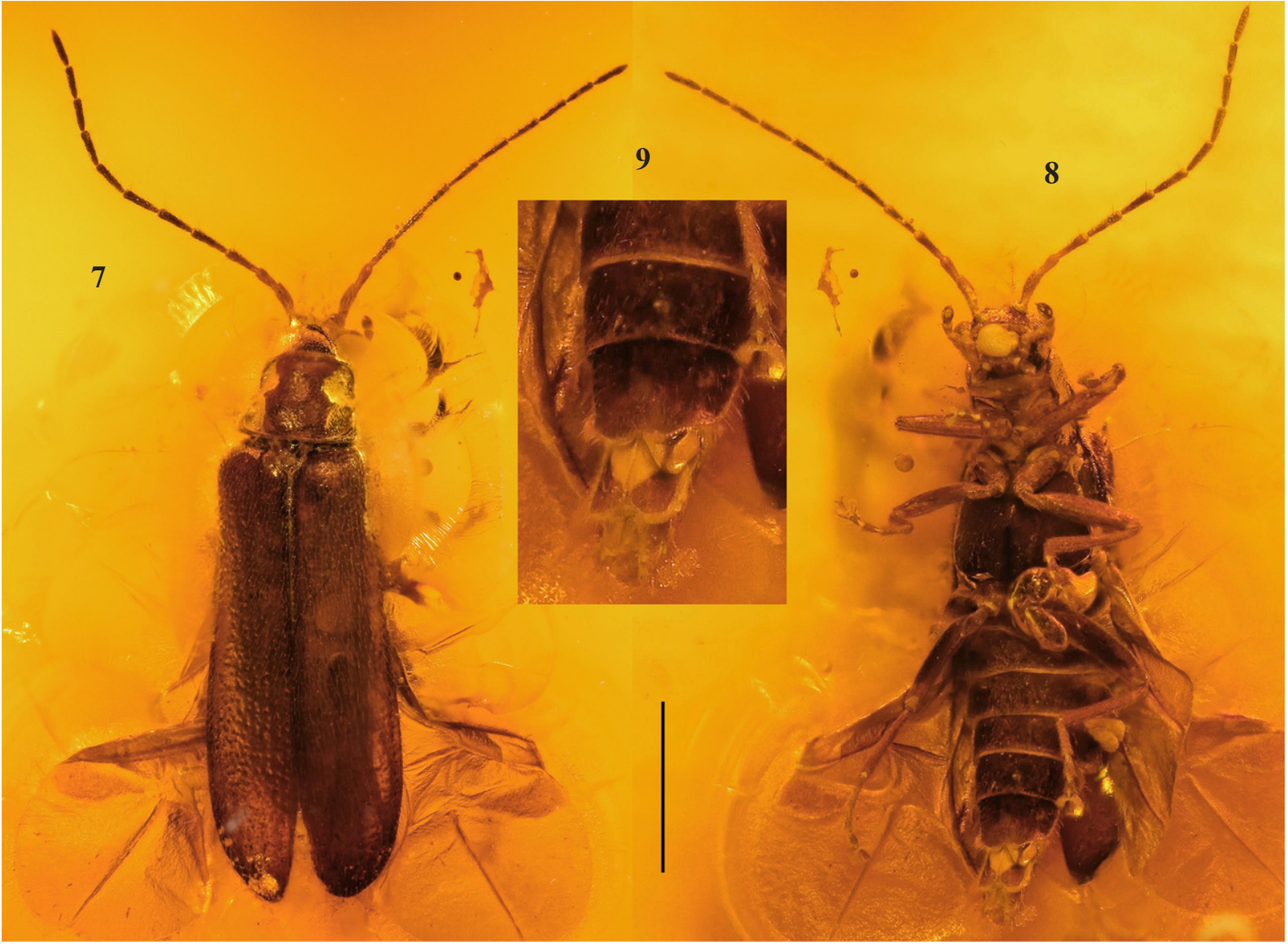

Figs 7-9. Details of Mimoplatycis notha, male: 7 - general view, dorsally; 8 - same, ventrally; 9 - terminal abdominal segments, ventrally. Scale bar (for Figs 7-8): $1 \mathrm{~mm}$.

Рис. 7-9. Детали строения Mimoplatycis notha, самец: 7 - общий вид, сверху; 8 - то же, снизу; 9 - вершинные сегменты брюшка, снизу. Масштаб (для рис. 7-8): 1 мм.

\section{Mimoplatycis notha Kazantsev 2013}

Figs 7-9

Mimoplatycis notha Kazantsev 2013: 288

MATERIAL: $0^{\text {t, }}$, specimen SIZK No. K-6089, Klesov, Rovno amber, Late Eocene; male, specimen SIZK No. UA-2286, Rovno amber, Late Eocene.

REMARKS. The other two known specimens of this taxon are from the Baltic amber: the holotype - from the Danish amber and the paratype - from the East Baltic amber (Kaliningrad oblast) [Kazantsev, 2013]. In one of the Rovno amber specimens the abdomen may be observed with greater detail (Figs 7-9), clearly showing six ventrites and allowing to suggest the occurrence of vestiges of the seventh ventrite making up a pair of divided ventral lobes of the aedeagus (Fig. 9).

\section{Cacomorphocerus sp.}

MATERIAL: ${ }^{\top}$, specimen SIZK No. K-541, Klesov, Rovno amber, Late Eocene.

SYNINCLUSIONS. One Diptera (Chironomidae).

REMARKS. The other known specimens of Cacomorphocerus Schaufuss, 1892 originate from the East Baltic amber [Schaufuss, 1892; Kus'ka \& Kania, 2010; Kazantsev, 2013].

ACKNOWLEDGEMENTS. It is our pleasant duty to express gratitude to A.P. Rasnitsyn (Moscow) for his valuable comments on the manuscript.

\section{References}

Förster B. 1891. Die Insekten des "Plattigen Steinmergels" von Brunstatt // Abhandlungen zur Geologischen Specialkarte von Elsass-Lothringen. Bd.3. S.335-595.

Kazantsev S.V. 2010. New Malthodes from the Rovno Amber (Insecta, Cantharidae, Coleoptera) (Upper Eocene of Ukraine) // Russian Entomological Journal. Vol.19. No.2. P.105-107.

Kazantsev S.V. 2013. New taxa of Baltic amber soldier beetles (Insecta: Coleoptera: Cantharidae) with synonymic and taxonomic notes // Russian Entomological Journal. Vol.22. No.4. P.283-293.

Kuśka A., Kupryjanowicz J. 2005. Soldier beetles (Coleoptera, Cantharidae) from Baltic amber // Polskie Pismo Entomologiczne. Vol.74. P.309-316.

Kuśka A., Kania I. 2010. New soldier beetles (Coleoptera, Cantharidae) from the Eocene Baltic amber // Zootaxa. Vol.2400. P.49-56.

Perkovsky E.E., Zosimovich V.Yu., Vlaskin A.P. 2010. Rovno Amber // D. Penney (ed.). Biodiversity of fossils in amber from the major world deposits. Manchester: Siri Scientific Press. P.116136.

Schaufuss C. 1892. Preussens Bernstein-Käfer. I. Neue Formen aus der Helm'schen Sammlung im Danziger Provinzialmuseum // Berliner Entomologische Zeitschrift (1891). Bd.36 Hf.1. S.5364. 